UDC [336.02:331.522.1]:339.9 DOI: http://doi.org/10.31617/k.knute.2019-10-10.14

Kalyuzhna Nataliya,

Doctor of Sciences (Economics), Professor, Kyiv National University of Trade and Economics (Ukraine) ORCID: 0000-0003-0513-705X

Researcher ID: L-8274-2016

\title{
UKRAINE AS A PARTY TO WTO TRADE DISPUTES
}

The significance of the WTO dispute settlement mechanism in preventing the escalation of interstate trade conflicts is substantiated. In order to formalize the results of the accession of countries to the system of global trade law, the coefficients of the effectiveness of the country's participation in WTO trade disputes in general and WTO consultations in particular are proposed. Based on the systematization of the experience of Ukraine's participation in WTO trade disputes, low values of the proposed coefficients have been shown, indicating ineffective using of possibilities of the WTO dispute settlement mechanism.

Keywords: trade dispute, effectiveness ratio, WTO consultations, trade conflict.

\section{Калюжна Наталія. Украӥна як сторона торговельних суперечок СОТ.}

У статті обтрунтовано значушість механізму врегулювання торговельних суперечок СОТ у попередженні ескалації міждержавних торговельних конфліктів. 3 метою оцінювання дієвості долучення держав до системи глобального торговельного права запропоновано коефіцієнти результативності участі держави у торговельних суперечках в цілому та використання механізму консультаиій СОТ зокрема. На основі систематизаиії досвіду участі України у торговельних суперечках підтверджено незадовільні значення обох коефіиієнтів, щзо свідчить про неефективне використання державою можливостей механізму вирішення торговельних суперечок СOT.

Ключові слова: торговельна суперечка, коефічієнт результативності, консультаиії СОТ, торговельний конфлікт.

Relevance of research topic. The WTO directs its activities to minimize the likelihood of the trade conflicts transformation into more rigid forms of confrontation between countries that is achieved through the application of a dispute settlement mechanism. The WTO dispute settlement mechanism is a central element that ensures the security and predictability of the international trading system and enables WTO member countries to resolve trade conflicts within the framework of international public law without resorting to the deployment of trade wars. 
Formulation of the problem. Since Ukraine's accession to the WTO, the country is actively involved in international cooperation within the framework of this organization, and participates in trade disputes in order to uphold national economic interests. Therefore, it becomes relevant to develop an approach to assess the effectiveness of state participation in WTO trade disputes.

Analysis of recent researches and publications. Such domestic scientists carried out the study of the theoretical aspects of the WTO dispute settlement as T. Hordeieva [1], L. Tykhonchuk [2], K. Flissak [3] and other. The researchers undoubtedly highlight the positive role of the WTO in establishing trade and economic relations between the countries as a whole and the importance of application by Ukraine instruments of global trade in particular. However, attempts to quantify and formalize the results of the accession states to the global trade law system are currently absent. For Ukraine the development of such approaches is in due time, since the results of the state's participation in WTO trade disputes are not in its favor in recent years.

Presenting main material. In our opinion, the obvious evidence for the high effectiveness of state participation in trade disputes is the number of such disputes regulated by the WTO in its favor or withdrawn by mutually agreed solution:

$$
K_{T D}^{S T}=\frac{n}{n_{\text {total }}} \times 100 \% \rightarrow \max ,
$$

where $K_{T D}^{S T}$ is the effectiveness ratio of the country's participation in WTO trade disputes; $n$ is a number of trade disputes involving a country that was regulated in its favor or withdrawn by mutually agreed solution; $n_{\text {total }}$ is a total number of trade disputes involving the country, regulated by the WTO.

The proposed ratio can take values ranging from $100 \%$ (the best case, resolving all trade disputes involving the country in its favor or by mutually agreed solution) to $0 \%$ (worst case, no precedents for resolving trade disputes involving the country in its favor or by mutually agreed solution).

If the country and its trading partners properly use the benefits of open and transparent consultations that precede the creation of an expert panel, they have the opportunity to resolve the dispute until it becomes a tough trade conflict. Involvement of any third parties (states, international organizations, profile specialists, etc.) at the consultations stage due to the transparency and openness of the dispute settlement mechanism increases the chances of their rapid settlement and reaching a compromise. However, if a trade dispute at the consultation stage is not resolved in favor of the state, this will only indicate the effectiveness of the dispute settlement mechanism as a whole, that is, the possibility of rapid decision-making in the WTO trade law system. Therefore, as an additional evidence of the effectiveness of state participation in trade disputes, in our opinion, it is advisable to consider the number of trade disputes completed in its favor or withdrawn by mutually agreed solution at the consultation stage: 


$$
K_{\text {CONS }}^{S T}=\frac{n_{\text {cons }}}{n_{\text {total }}} \times 100 \% \rightarrow \max ,
$$

where $K_{C O N S}^{S T}$ is the effectiveness ratio of the country's participation in WTO consultations; $n_{\text {cons }}$ is a number of trade disputes involving a country that was settled / withdrawn at the consultation stage in its favor or by mutually agreed solution; $n_{\text {total }}$ is a total number of trade disputes involving the country, regulated by the WTO.

The proposed ratio can take values ranging from $100 \%$ (the best case, resolving all trade disputes involving the country at the consultation stage in its favor) to $0 \%$ (worst case, no precedents for resolving trade disputes involving the country at the consultation stage in its favor or by mutually agreed solution).

Despite the fact that Ukraine has relatively recently become a WTO member, the country has some experience in participating in the WTO dispute settlement system both as a complainant (dispute-initiating party) and as a defendant (the country against which the dispute is initiated). Practical experience of Ukraine's participation in WTO trade disputes as both complainant and defendant is considered for example in [4].

We will assess the effectiveness of Ukraine's participation in WTO trade disputes, guided by data on the number and status of the trade disputes settlement initiated by Ukraine against other countries and other countries against Ukraine (table 1). As can be seen from table 1, since the moment of accession to WTO, Ukraine has initiated nine trade disputes against other countries. Of these, one dispute was actually settled at the consultation stage (dispute over Armenia regarding measures affecting the importation and internal sale of cigarettes and alcoholic beverages DS411, commenced on 20/07/2010). Ukraine withdrawn the request for the establishment of a dispute panel on 08/09/2010.

The dispute with Moldova numbered as DS421, regarding environmental charge (started on 17/02/2011), was settled on 17/06/2011 after the Dispute Settlement Body (DSB) established a dispute panel. Dispute DS434 with Australia regarding measures concerning tobacco plain packaging (started on 13/03/2012) was settled when Ukraine requested the dispute panel to suspend its proceedings in a view to finding a mutually agreed solution.

Following the initiated by Ukraine on 21/10/2015 a trade dispute with the Russian Federation concerning restrictive measures affecting the importation of railway equipment (DS499), a dispute panel released report in July 2018, which showed that the resolution of the dispute was not in the interests of Ukraine. In this case WTO confirmed the validity of the Russian Federation to certify Ukrainian rail products in view of the danger of visiting Russian specialists to Ukrainian enterprises [6]. Despite the fact that in August of the same year Ukraine appealed to the Appellate Body (AB), such a decision of the WTO dispute panel created the grounds for Ukraine's loss in the next transit dispute. 
Ukraine as a party to WTO trade disputes (composed by the author based on [5]

\begin{tabular}{|c|c|c|c|c|c|c|c|c|c|}
\hline $\begin{array}{l}\text { Comp- } \\
\text { lainant }\end{array}$ & Respondent & Title & $\begin{array}{l}\text { Request } \\
\text { for } \\
\text { consultati } \\
\text { on }\end{array}$ & $\begin{array}{l}\text { Request } \\
\text { for es- } \\
\text { tablish- } \\
\text { ment }\end{array}$ & $\begin{array}{l}\text { Dispute } \\
\text { Panel } \\
\text { esta- } \\
\text { blished }\end{array}$ & $\begin{array}{l}\text { Dispute } \\
\text { Panel } \\
\text { comp- } \\
\text { osed }\end{array}$ & $\begin{array}{c}\text { Dispute } \\
\text { Panel } \\
\text { report } \\
\text { circu- } \\
\text { lated }\end{array}$ & $\begin{array}{l}\text { Dispute } \\
\text { Panel / } \\
\text { AB report } \\
\text { adopted }\end{array}$ & Current status \\
\hline Ukraine & Armenia & $\begin{array}{l}\text { DS411: Measures Affecting the } \\
\text { Importation and Internal Sale of } \\
\text { Cigarettes and Alcoholic Beverages }\end{array}$ & 20.07 .10 & 08.09 .10 & & & & & \multirow{2}{*}{ Mutually agreed solution } \\
\hline Ukraine & Moldova & $\begin{array}{l}\text { DS421 : Measures Affecting the } \\
\text { Importation and Internal Sale of Goods } \\
\text { (Environmental Charge) }\end{array}$ & 17.02 .11 & 12.05 .11 & 17.06 .11 & & & & \\
\hline Moldova & Ukraine & DS423 : Taxes on Distilled Spirits & 02.03 .11 & 01.06 .11 & 20.07 .11 & & & & $\begin{array}{c}\text { Withdrawn in } \\
\text { complainant's interests }\end{array}$ \\
\hline Ukraine & Australia & DS434 : Tobacco Plain Packaging & 13.03 .12 & 14.08 .12 & 28.09 .12 & 05.05 .14 & 28.06 .18 & & Mutually agreed solution \\
\hline Japan & Ukraine & DS468 : Passenger Cars & 30.10 .13 & 13.02 .14 & 26.03 .14 & 20.06 .14 & 26.06 .15 & 20.07 .15 & \multirow{2}{*}{$\begin{array}{c}\text { Resolved in complainant's } \\
\text { interests }\end{array}$} \\
\hline Russia & Ukraine & DS493 : Ammonium Nitrate & 07.05 .15 & 29.02 .16 & 22.04 .16 & 02.02 .17 & 20.07 .18 & & \\
\hline Ukraine & Russia & $\begin{array}{l}\text { DS499 : Measures Affecting the } \\
\text { Importation of Railway Equipment and } \\
\text { Parts Thereof }\end{array}$ & 21.10 .15 & 10.11 .16 & 16.12 .17 & 2.03 .17 & 30.07 .18 & 27.08 .18 & \multirow[t]{2}{*}{$\begin{array}{l}\text { Resolved not in Ukraine's } \\
\text { favor }\end{array}$} \\
\hline Ukraine & Russia & DS512: Traffic in Transit & 14.09 .16 & 09.02 .17 & 21.03 .17 & 07.06 .17 & 05.04 .19 & 26.04 .19 & \\
\hline Russia & Ukraine & $\begin{array}{l}\text { DS525: Measures Relating to Trade in } \\
\text { Goods and Services }\end{array}$ & 19.05 .17 & & & & & & \multirow{5}{*}{ In consultation } \\
\hline Ukraine & Kazakhstan & $\begin{array}{l}\text { DS530 : Anti-Dumping Measures on } \\
\text { Steel Pipes }\end{array}$ & 19.09.17 & & & & & & \\
\hline Ukraine & Russia & $\begin{array}{l}\text { DS532: Measures concerning the } \\
\text { Importation and Transit of Certain } \\
\text { Ukrainian Products }\end{array}$ & 16.10 .17 & & & & & & \\
\hline Ukraine & $\begin{array}{l}\text { Kyrgyz } \\
\text { Republic }\end{array}$ & $\begin{array}{l}\text { DS569 : Anti-Dumping Measures on } \\
\text { Steel Pipes }\end{array}$ & 17.10 .18 & & & & & & \\
\hline Ukraine & Armenia & $\begin{array}{l}\text { DS570 : Anti-Dumping Measures on } \\
\text { Steel Pipes }\end{array}$ & 17.10 .18 & & & & & & \\
\hline
\end{tabular}


Another trade dispute with Russia regarding measures for restricting traffic in transit (DS512, started on 14/09/2016) the WTO dispute panel settled not to the benefit of Ukraine too. Such unsatisfactory result has as an important geopolitical significance, since, according to experts [6], it is a key trade dispute between countries during Ukraine's membership in the WTO. In addition, Ukraine's submission of a complaint about the lawfulness of the application of Art. XXI GATT created a precedent in world trade law. There was no experience of settling transit disputes by the WTO until this case, whereas their number would increase sharply in view of the escalating interstate trade conflicts and the implementation of new foreign trade restrictions.

In this trade dispute, Ukraine was trying to stand up the right to transport goods to the Central Asian post-Soviet republics and Mongolia. The formal reason for initiating this case by Ukraine was the violation by the Russian Federation the GATT regulations regarding to the prohibition of discrimination of goods transit by the WTO member states (Art. V). In turn, the Russian Federation motivated its actions by another norm (GATT: Art. XXI), which allows the implementation of protective measures in the event of a threat to national security. Acceptance Ukraine's complaint of for the first time has certified the legality of addressing the issues of national security threats in the area of global trade law. Nevertheless, the dispute panel made a decision in favor of Russia. The WTO experts did not recognize transit restriction as a violation because of imagined threats to the national security of the Russian Federation due to the political situation in Ukraine in 2014-2015. The breakdown of the shortest path of Ukrainian goods to Asian markets has led to a reduction of domestic exports to Central Asia from \$ 3.1 billion in 2013 to \$ 0.8 billion in 2018 . The trade balance with Asian countries actually fell to zero compared with the surplus of $\$ 2.22$ billion in 2013 .

The decision of WTO experts in the dispute DS512 weakens Ukraine's position in the context of another trade dispute with the Russian Federation concerning the importation and transit of certain Ukrainian products (DS532, started on 16/10/2017). For almost two years, Ukraine has not asked for the creation of a dispute panel, which means a refusal to consider dispute without its withdrawing.

Finally, there are three disputes between Ukraine and the CIS countries (Kazakhstan, Kyrgyzstan and Armenia) in consultations, regarding anti-dumping measures on steel pipes (respectively, DS530 dated 19/09/17, DS569 dated 17/10/18, and DS570 dated 17/10/18). For these disputes, no dispute panel established and no withdrawal or mutually agreed solution notified.

Thus, out of nine trade disputes initiated by Ukraine in WTO, in favor of the state one dispute was settled by mutually agreed solution at the consultation stage (DS411), two at the stage of dispute panel establishment (DS421, DS434). The dispute panel decisions on trade disputes DS499 and DS512 were not made in the interests of Ukraine. Four disputes are at the consultation stage, but the expiration of the 12-month 
period for two of them (DS530 and DS532) suggests that Ukraine has refused claims to defendants.

As to disputes initiated by other countries against Ukraine, the dispute with Moldova regarding the taxes on distilled spirits (DS423, started on 02/03/2011) was dealt with in fact during the consultation stage, since the request for the creation an expert panel was withdrawn after Ukraine ceased to apply a reduced rate of excise tax. The dispute with Japan on special measures for passenger cars (DS468, started on 30/10/2013) has been resolved at the stage of expert panel report. In a dispute initiated by Russia (anti-dumping measures on ammonium nitrate, DS493, started on $7 / 05 / 2015$ ), WTO experts satisfy the complaint regarding the introduction of protective duties on Russian ammonium nitrate by Ukraine. Another dispute with Russia regarding trade in goods and services (DS525, started on 19/05/2017) is at the consultation stage. The complaint of the Russian Federation in this case concerns the appeal of Ukrainian sanctions, in defense of which Kyiv will refer to the already mentioned GATT: Art. XXI. The symmetry of these disputes creates grounds for Ukraine's optimistic expectations regarding the results of the work of WTO experts.

Thus, out of the four trade disputes initiated against Ukraine, one is in the process of consultations, while expert panel regulates the other three not in favor of Ukraine. According to formulas (1) and (2), we can determine the ratios proposed for evaluating the effectiveness of the state's participation in trade disputes:

$$
\left\{\begin{array}{l}
K_{T D}^{S T}=\frac{n}{n_{\text {total }}} \times 100 \%=\left(\frac{3+0}{9+4}\right) \times 100 \%=23 \% \\
K_{\text {CONS }}^{S T}=\frac{n_{\text {cons }}}{n_{\text {total }}} \times 100 \%=\left(\frac{1+0}{9+4}\right) \times 100 \%=7,7 \%
\end{array}\right.
$$

Conclusion. The value of the two proposed ratios is low, which indirectly indicates the unsatisfactory results of Ukraine's participation in WTO trade disputes. In the interests of Ukraine (more precisely, by mutual agreed solution of the parties), three disputes of thirteen were settled, but only one of them - at the consultation stage. This fact caused the value of the effectiveness ratios at the level of $23 \%$ and $7.7 \%$ respectively, at their potentially achievable value of $100 \%$. Because of the aggravation of political relations, Ukraine has the largest number of trade disputes with Russia, and the decisions of WTO experts on these disputes are consistently taken not in favor of our state. In addition, for the effective application of the WTO dispute settlement tool, the proactive engagement of interested business and government stakeholders should be provided. Therefore, there is a need for the development of public-private partnership for optimal and effective use of adequate WTO mechanisms to protect Ukraine's national interests. 


\section{REFERENCES}

1. Hordeieva T. (2013). Mizhnarodni torhovelni superechky u suchasnii rehuliatyvnii paradyhmi [International trade disputes in the current regulatory paradigm]. Mizhnarodna ekonomichna polityka - International economic policy, 2, 101-125. Retrieved from http://journals.uran.ua/jiep/article/view/27762 [in Ukrainian].

2. Tykhonchuk L. (2018). Osoblyvosti implementatsii mizhnarodnykh standartiv vrehuliuvannia mizhnarodnykh torhovykh sporiv Ukrainy na osnovi protsesualnykh mekhanizmiv SOT [Features of implementation of international standards of settlement of international trade disputes of Ukraine on the basis of WTO procedural mechanisms]. Investytsii: praktyka ta dosvid - Investment: practice and experience, 2, 91-96. Retrieved from http://www.investplan.com.ua/?op=1\&z= $5898 \& \mathrm{i}=16$ [in Ukrainian].

3. Flissak K. (2016). Mizhnarodni torhovelni spory i mistse ekonomichnoi dyplomatii u yikh vrehuliuvanni [International trade disputes and the place of economic diplomacy in their settlement]. Aktualni problemy mizhnarodnykh vidnosyn Actual problems of international relations, Vol. 127. Is. 2, 152-164 [in Ukrainian].

4. Posibnyk shchodo mekhanizmu vrehuliuvannia superechok u ramkakh Svitovoi orhanizatsii torhivli [Handbook on the Dispute Settlement Mechanism within the World Trade Organization]. (n.d.) me.gov.ua [in Ukrainian].

5. World Trade Organization. WTO Dispute Settlement. Retrieved from http://www.wto.org/english/tratop_e/dispu_e/dispu_e.htm [in English].

6. Panchenko Yu. (2019). Tretia porazka u SOT: yaki naslidky matyme proval $\mathrm{u}$ tranzytnii superechtsi z RF [The third defeat in the WTO: what consequences will fail in a transit dispute with the Russian Federation]. Retrieved from https://www.eurointegration.com.ua/articles/2019/04/5/7094801/ [in Ukrainian]. 